Iberian Journal of the History of Economic Thought

ISSN: 2386-5768

\title{
William Stanley Jevons and Francis Ysidro Edgeworth: Two Pioneers of Happiness Economics $^{1}$
}

\author{
Miren Maite Ansa Eceiza²; Francisco Gómez García ${ }^{3}$
}

Enviado: 11 de julio de 2018 / Aceptado: 16 de julio de 2019

\begin{abstract}
This paper opens up with some issues which are fundamentally relevant to how Happiness Economics studies are presently conducted, and then sets out to show that for prominent neoclassical authors W. S. Jevons and F. Y. Edgeworth the object of Economics was to maximise happiness and that, in this, they coincide with current economists working in this research area. We show that the interest in happiness is not new but leans on a significant economic tradition linked to the Utilitarian philosophy that dates to the second half of the $19^{\text {th }}$ century.
\end{abstract}

Keywords: happiness, economics of happiness, neoclassical economics, utilitarian philosophy

JEL Classification: B13, B41

[es] William Stanley Jevons y Francis Ysidro Edgeworth: dos pioneros de la Economía de la Felicidad

Resumen. Este artículo primero aborda temas relevantes para la forma en que actualmente se realizan los estudios de Economía de la Felicidad y más tarde muestra que para W.S. Jevons y F.Y. Edgeworth, autores neoclásicos fundamentales, el objetivo de la Economía era maximizar la felicidad. En esto, coinciden con los economistas actuales que trabajan en esta área de investigación. Se muestra que el interés por la felicidad no es nuevo, sino que se apoya en una importante tradición económica vinculada a la filosofía utilitaria que data de la segunda mitad del siglo XIX.

Palabras clave: felicidad, economía de la felicidad, economía neoclásica, filosofía utilitaria.

Clasificación JEL B13, B41

Sumario: 1. Introduction. 2. Happiness Economics as an emerging research line. 3. An examination of the origins of Happiness Economics. 4. Conclusions. References

Cómo citar: Ansa Eceiza, M.; Gómez García, F. (2019) William Stanley Jevons and Francis Ysidro Edgeworth: Two Pioneers of Happiness Economics, en Iberian Journal of the History of Economic Thought 6(2) (2019), 175-187.

We would like to thank Luis Palma and Karin Tailbot, the two anonymous referees, and the editors for their helpful discussions and comments.

2 Universidad del País Vasco; maite.ansa@ehu.eus

Universidad de Sevilla; fgomez@us.es 


\section{Introduction}

The professed object of Dr. Adam Smith's inquiry is the nature and causes of the wealth of nations. There is another inquiry, however, perhaps still more interesting, which he occasionally mixes with it, I mean an inquiry into the causes which affect the happiness of nations.

T.R. Malthus (1798)

This quote from Malthus evidences an interest in investigating the causes that affect well-being and happiness. That interest has always been -and indeed continues to be- an area of reflection and study for numerous social scientists all over the world ${ }^{3}$. Some degree of reproach towards Smith can be observed for not having investigated more into the matter of how, when and under what conditions wealth turns into happiness. In spite of this critique, when Malthus wrote his Principles of Political Economy in 1820, he stated that the essential object of political economy was to "inquire into the causes which influence the progress of wealth" (Malthus, 2008 [1820]: 29) .

Luigi Pasinetti argues that Malthus and other classical economists had to face the task of building the foundations of a new science. They could not have undertaken this task if they had not focused on a variable such as wealth, that is a topic of inquiry more restricted than happiness, but which can be defined objectively (Pasinetti, 2005).

The way this issue was approached changed in the second half of the $20^{\text {th }}$ century with the advent of the first neoclassical economists. Influenced by Bentham's utilitarianism, they ceased to concern themselves with the objective concept of wealth and switched to the subjective concept of happiness, a term that the first neoclassical cardinalists saw as a synonym of pleasure, utility, well-being or satisfaction. In neoclassical theory the value of a good is no longer considered to be determined by the amount of work needed to produce it, but rather by the amount of pleasure or happiness that it provides to whoever owns or uses it (Colander, 2007).

In this article we will first look at some of the main issues regarding Happiness Economics $^{5}$ at present, and will then set out to show that for W.S. Jevons and F.Y. Edgeworth, two prominent neoclassical authors, the object of economics was to maximise happiness, an aspect in which they coincide with current happiness economists. In other words, we seek to show that the interest of happiness economists is not new but is backed up by a significant economic tradition linked to utilitarian philosophy that dates to the second half of the $19^{\text {th }}$ century.

The question arises of whether it is possible to know for sure what makes us happy. In this sense, German philosopher Immanuel Kant warned that "The problem of determining surely and universally which action would promote the happiness of a rational being is completely insoluble" because happiness "is not an ideal of reason but of imagination" (Kant, 2007 [1785]: 33).

Despite Kant's warning, there is currently considerable interest in the measurement of happiness and its causes, in both academic and political circles. A case in point is the publication on 14 September 2009 of the Report by the Commission on the Measurement of Economic Performance and Social Progress ${ }^{6}$, known as the Stiglitz-Sen-Fitoussi Report, drawn up by 25 prominent social scientists, including five winners of the Nobel Prize for Economics. Their remit was to prepare statistical data and indicators capable of properly measuring economic and social progress (Stiglitz et al., 2009a).

The authors of the report maintain that "measures of both objective and subjective well-being" -life satisfaction, happiness- "provide key information about people's quality of life" and therefore "statistical offices should incorporate questions to capture people's own life evaluations, hedonic experiences and priorities in their own survey" (Stiglitz et al., 2009b: 15).

A classic reference on his topic is Veblen (1989 [1899]). Other major studies that deserve to be highlighted include Russell (2006 [1930]), Hirsch (1976), Scitovsky (1976) and Galbraith (2008 [1958]). We could go back in time, to the Greek Classical period, during which the concern of thinkers was the improvement of people's happiness.

The publication dates indicated are those of the Spanish-language versions of the text used as the basis for this study.

For recent reviews in this field see the papers by Frey (2008), Rojas (2009) and Ferrer-i-Carbonell (2011 \& 2013).

In February 2008 Nicolas Sarkozy asked Joseph Stiglitz (Chair), Amartya Sen (Advisor) and Jean Paul Fitoussi (Coordinator) to set up a commission, which took the name Commission on the Measurement of Economic Performance and Social Progress. Its mission was to "identify the limits of GDP as an indicator of economic performance and social progress, including the problems with its measurement; to consider what additional information might be required for the production of more relevant indicators of social progress; to assess the feasibility of alternative measurement tools, and to discuss how to present the statistical information in an appropriate way" (Stiglitz et al., 2009b). 
In short, knowledge of the causes that promote people's subjective well-being is of interest at both individual and institutional levels. Happiness Economics uses the responses given by individuals in surveys when they are asked about their levels of life satisfaction and happiness, to look for correlations and seeks to quantify the influence of variables such us income, employment, health, education, etc. on people's declared subjective well-being.

The following section looks at Happiness Economics as a line of research that began to emerge in the 1970s and has become more widespread in the opening years of the $21^{\text {st }}$ century. Section 3 focuses on the economic analysis of happiness in the writings of Jevons and Edgeworth. Section 4 sets out the main conclusions of our study.

\section{Happiness Economics as an emerging research line ${ }^{7}$}

As stated above, there is currently an upsurge in interest in happiness as a topic for economic analysis. According to Cachón (2013), Happiness Economics is a current of economic analysis that questions the role of wealth as the prime explanatory variable for well-being and holds that the economy exists because of and for individuals, with the object of raising levels of both individual and collective well-being. Oswald (1997) had already raised this question in his assertion that "the relevance of economic performance is that it may be a means to an end. That end is not consumption of beef burgers, or the accumulation of television sets, not the vanquishing of some high level of interest rates, but rather the enrichment of mankind's feeling of well-being. Economic things matter only in so far as they make people happier".

This line of research holds that income does not determine the happiness of an individual and economic benefits are not an end in themselves for society. This emerging discipline can be said to dethrone many of the assumptions of conventional economic analysis. The approach has been widely accepted, to the extent that it is gaining ground among many governments and institutions such as the OECD and the European Commission -Sustainable Development Goals (SDGs).

\subsection{Outstanding earlier work}

The reason why it has taken so long for economics to be incorporated into the realm of happiness may be the reluctance of economists to use subjective variables. Peiró (2004) argues that the lack of interest in studying individual well-being could stem from new ordinal theories of utility or from the belief that it is not possible to measure happiness. It seems that the first major reference point in what is now known as Happiness Economics ${ }^{8}$ is a paper led by psychologists rather than economists: Brickman \& Campbell (1971) examine individual and collective happiness and conclude that improvements in individual wealth and income do not necessarily result in real improvements in people's well-being.

These conclusions in turn influenced papers by two other researchers who were indeed economists: Richard Easterlin (1974) and Tibor Scitovsky (1976). Both these authors looked at the role played by income as a determinant for happiness. In his 1974 paper, the US-born Easterlin used the results of his own empirical research as the basis for asserting that per capita income in the USA had doubled from 1946 to 1970, while happiness had barely increased over the same period.

Along the same lines, Scitovsky (1976) sought to explain why the comfortable lifestyle enjoyed by wealthy, developed societies could lead to feelings of frustration and emptiness in the citizens of these countries, i.e. why a high level of material well-being did not seem to translate directly to a high level of personal happiness.

Another major reference point in Happiness Economics can be found in three pioneering studies published in The Economic Journal in November 1997 by Andrew Oswald, Robert Frank and Yew Kwang Ng. These papers sought mainly to open up a debate concerning the im-

Most authors, see for example Clark (2016), use the terms happiness, utility and, among others, satisfaction interchangeably. The analysis of the small differences and nuances between these terms exceeds the scope of this article.

8 Nor must it be forgotten that the earliest influences evidenced in later studies in this field come from schools of classical philosophy. The first is hedonism, as championed by Epicurus, which defended the realisation of all individual pleasures and saw them as the source of individual happiness. Eudaemonics, of which Aristotle was the main proponent, attributes a highly important role to political or social life as a determinant of happiness. In this context, Smith (1759) and Smith (1776) should be compared and contrasted. 
portance of happiness in the field of economic analysis. They argued that it made sense to measure happiness and that happiness should once again play a core role in the Economic science (Oswald, 1997; Frank, 1997; Ng, 1997).

Finally, we must also mention the contribution made by the economist Richard Layard (2005) of the London School of Economics, who argues in favour of government intervention in matters of taxation and education in order to promote general happiness. He maintains that to raise satisfaction levels among the public, the degree of competitive struggle between individuals for socio-economic status (the "rat race") must be reduced. One of his main arguments is that the individual struggle for economic and social status generates negative externalities that must be combated if higher aggregate levels of happiness are to be attained. We conclude this section with a special mention to Angus Deaton, winner of the Nobel Prize for Economics (2015), clearly a Happiness Economist.

\subsection{The Easterlin paradox}

In 1974 Easterlin published a paper that is generally regarded as one of the main precursors of the Economics of Happiness. Its title is Does Economic Growth Improve The Human Lot? Some Empirical Evidence. Easterlin begins by citing Moses Abramovitz's work The Welfare Interpretation of National Income and Product (Abramovitz, 1959), in which the author concludes that we should be highly sceptical about the idea that rates of increase in long-term well-being can be measured, even approximately, on the basis of growth rates in output (Abramovitz, 1959: 1-2).

This scepticism led Abramovitz to call on the profession to conduct theoretical reflections and empirical studies that could shed light on the true nature of the relationship between economic growth and general well-being. Easterlin states that his paper was intended as a response to Abramovitz's call (Easterlin, 1974: 89).

Accordingly, he tackles the question of the link between income and happiness from an empirical viewpoint, covering the period between 1946 and 1970 and including 19 countries, some of them highly developed and others less so, using data from 30 different investigations.

In this context, the main question asked by Easterlin was this: is there any evidence to sug- gest that economic growth is positively associated with social well-being, i.e. with human happiness? (Easterlin, 1974: 90). The findings of his study can be summed up as follows:

1. For a given country in each time period, Easterlin finds clear indications that income and happiness are positively correlated, i.e. that those individuals who enjoy the highest social status are on average happier than those with a lower status (Easterlin, 1974: 99-100);

2. When comparisons are drawn between countries there is no clear evidence that those countries which are wealthier on average are, as might have been expected, happier on average (Easterlin, 1974: 106).

3. When studying time series for the case of the USA, he finds no clear evidence that increases in income over time are paralleled by increases in subjective happiness (Easterlin, 1974: 110-111).

Results 2 and 3 can be seen as contradicting result 1 . This contradiction has become known in the literature on Happiness Economics as the "Easterlin paradox".

Easterlin himself explains the paradox as essentially based on James Duesenberry's relative income theory. This theory states that an increase in the income of a single individual may increase his own happiness, but an equivalent increase for all individuals could result in there being no change in the level of happiness (Duesenberry, 1972: 66). In this context, it can be argued that economic growth does not necessarily result in an increase in the level of happiness of citizens.

Two more important explanations stem from the field of psychology: the psychologist and winner of the Nobel Prize for Economics Daniel Kahneman has popularised the image of the treadmill as a metaphor for a situation in which people strive to move forward in terms of income but are unaware that those movements hardly give rise to any progress in terms of happiness after the first few moments of euphoria (Kahneman \& Sugden, 2005).

These treadmills include the "hedonic treadmill", on which people get used to having more income after a time, and the "aspirational treadmill", on which having more income leads people to aspire to having still more. Psychologists argue that the operation of these two psychological mechanisms can mean that 
increases in income hardly result in any increases in happiness in the long term.

For his part, Tibor Scitovsky offers quite an original explanation for the happiness paradox, based on a distinction between two sensations or feelings of a subjective nature: pleasure and comfort. He suggests that advanced societies must choose between the two, which could become mutually exclusive. Thus, continuously experiencing the maximum level of comfort would take away the inherent pleasure of gradually attaining higher levels of comfort. In this context the author argues that in today's advanced societies we have and pay for more comfort than we need for a good life and that our comforts can actually eliminate from our environment some of the most important pleasures for a happy life (Scitovsky, 1976).

Finally, for the case of the USA, some authors argue that one possible explanation for the slight drop in the level of subjective well-being in the country from 1972 to 2006 could be that the benefits of economic growth have been distributed among the people in a markedly unequal fashion (Stevenson \& Wolfers, 2008: 24) 9 .

It has also been argued that there has been not only an increase in the inequality of income distribution, as measured by indices such as that of Gini, but also an extreme concentration of income increases in high and very high income brackets $^{10}$ (Hacker \& Pierson, 2010: 155-156).

In short, the Easterlin paradox refers to the fact that increases in per capita income are not accompanied by parallel increases in the subjective feeling of satisfaction with life as declared by the population questioned in surveys on the matter.

Other authors, such as Iglesias et al. (2013), maintain that the paradox alludes to the fact that increases in income levels do not give rise to increases in levels of collective well-being, even though there is a direct link between income and well-being on an individual level. In other words, what goes for individuals cannot be generalised to the population as a whole.
But strictly speaking Happiness Economics did not emerge until the 1970s, and it is not confined solely to the happiness-income paradox. The following section of this article looks at the origins of this line of research, focussing on the contributions made by Jevons and Edgeworth to the field.

\section{An examination of the origins of Happiness Economics}

For classical economists (Smith, Malthus, Ricardo, Marx) the focus of economic analysis was mainly located in the study of macroeconomic issues such as the wealth of nations, the production and distribution of income and international trade. However in the second half of the $19^{\text {th }}$ century economists turned the focus of their interest away from macroeconomics towards microeconomics. Joan Robinson describes this change in emphasis as a shift away from classical economics' big questions of development and distribution towards questions of little importance such as "why does an egg cost more than a cup of tea?" (Robinson, 1953: 22).

This shift in the centre of interest of economic analysis also extended to the abandonment of the "labour theory of value" in favour of the "utility theory of value". Classical economists held that the value of a good stemmed from the amount of socially necessary labour to produce it, while neoclassical economists saw the value of a good as depending on the satisfaction/ happiness/utility that it provided to its holder or consumer. In that context the measurability of utility (or its equivalents) became an issue of particular importance (Colander, 2007: 216).

In short, the advent of marginal analysis led economics away from dealing with the objective concept of wealth and into dealing with happiness interpreted as utility, a subjective concept with psychological connotations, linked to the idea of satisfying human needs ${ }^{11}$. Bruni (2007) sustains that we are dealing here with the methodological project of Jeremy Bentham, which fed into economics thanks to the work of Wil-

9 Indeed in the 40 years from 1967 to 2007 , the Gini coefficient changes from 0.36 to approximately 0.44 , which has led some authors to argue that one of the most profound changes in the USA in the last forty years has been the growth of income inequality between social classes (Oishi et al., 2011: 1095).

10 The proportion of income (before tax) that goes to the top $1 \%$ of richest individuals increased from $8 \%$ in 1974 to $18 \%$ by 2007 (Hacker \& Pierson, 2010: 156). If capital gains and dividends from investment are included, the rise in the proportion of income that goes to the top $1 \%$ was from around $9 \%$ to $23.5 \%$ over that period. Data for the top $0.1 \%$ richest people in the USA (around 150,000 families) shows that their percentage of total income rose from $2.7 \%$ to $12.3 \%$, i.e. increased by almost 4.5 -fold; finally, the figure for the $0.01 \%$ richest (15,000 families) rose from below $1 \%$ in 1974 to over $6 \%$ in 2007 (Hacker \& Pierson, 2010: 155).

11 The influence of Benthamite philosophy can be observed here. 
liam Stanley Jevons and Francis Ysidro Edgeworth. Psychology thus entered headlong into economic analysis, though with the turn of the century (Pareto's ordinal utility analysis), it would be expelled once again (Edwards, 2009). As seen above, it was not until the 1970s that it was rescued-seemingly for good this time.

\subsection{William Stanley Jevons (1835-1882)}

Jevons was a leading follower of the utility theory and a confirmed Utilitarian ${ }^{12}$ (Schumpeter, 1982: 1147). He expressly acknowledged his indebtedness to Jeremy Bentham, whose ideas he adopted as the starting point for his own economic theories based entirely on calculating pleasure and pain. For Jevons the object of economics is to maximise happiness by gaining pleasure while minimising the cost in terms of pain. He has no hesitation in accepting the Utilitarian theory of morals, that upholds the effect of the actions of the agents on the happiness of mankind, as the criterion of what is right and wrong (Jevons, 1998: 81). This is how happiness, fully identified with pleasure, found its way into the mainstream as the new object of the new science of economics (Bruni, 2006:105).
In this context there is a need to exactly define what is meant by pleasure and by pain. Jevons proposes the following: "Call any motive which attracts us to a certain course of conduct, pleasure; and call any motive which deters us from that conduct, pain". He argues that it becomes impossible to deny that all human actions are governed by pleasure and pain (Jevons, 1998: 83).

Jevons explains that the intensity of feelings of pleasure and pain can be estimated at a moment in time as the total amount of feelings produced in each period. He goes on to cite Bentham, albeit in simplified form, and maintains that the circumstances to be considered when estimating a pleasure or pain are the following: intensity, duration, (un)certainty and proximity or distance. By way of example, he states that "Two days of the same degree of happiness are to be twice as much desired as one day; two days of suffering are twice as much feared" (Jevons, 1998: 86).

Jevons continues to simplify the problem until he reduces feelings of pleasure and pain to just two dimensions: duration and intensity. He proposes that time be measured on the $\mathrm{x}$-axis (x) and intensity on the $\mathrm{y}$-axis $(\mathrm{y})$ :

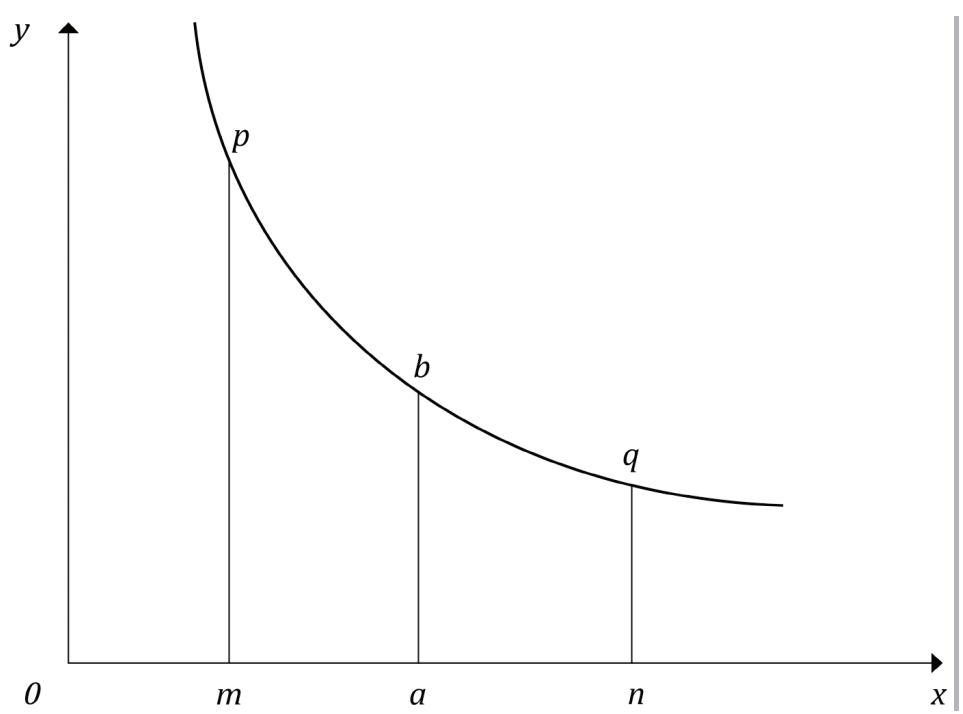

Figure 1: Total amount of feeling produced in different time periods. Source: (Jevons, 1998: 87)

12 As is well known, traditional microeconomic theory takes on board the Utilitarian philosophy of human behaviour according to which all individuals seek to maximise their own happiness. This means that individuals will make decisions only after a hedonistic calculation in which they weigh up the pleasures and pains inherent in every action or activity. Neoclassical economists took this approach as the basis for constructing their theory of value. They assumed that individuals acted as if they were equipped with a psychological mechanism that enabled them to measure and compare the pleasure and pain associated with different actions. Just as a thermometer measures the temperature, this alleged mechanism would measure the happiness or utility inherent in the various economic options available. In this context, the concepts of utility and happiness were considered to be largely synonymous. The concept of utility devised by Utilitarian economists was also cardinal in nature, i.e. measurable and comparable, like temperature or length (Esteve, 2008: 7; Esteve \& Muñoz de Bustillo, 2005: 608-609). 
He also sustains that the proper representation of the variation of feeling can be found in a curve "of more or less complex character. [...] The height $[\ldots]$ of the curve $p q$ above the horizontal line $o x$ indicates the intensity of feeling in a moment of time; and the whole quantity of feeling generated in the time period $m n$ is measured by the area bounded by the lines $\mathrm{pm}$, $q n, m n$ and $p q "$ (Jevons, 1998: 87-88).

Along the same lines, Jevons argues that feelings can also be anticipated -an idea close to what would now be referred to as "expectations". He believes that there must always be a link between the amount of feeling anticipated and the amount that is actually felt. Thus the intensity of present anticipated feeling "must, to use a mathematical expression, be some function of the future actual feeling and of the intervening time, and it must increase as we approach the moment of realisation [...] We may safely call that man happy who, however lowly his position and limited his possessions, can always hope for more than he has, and can feel that every moment of exertion tends to realise his aspirations" (Jevons, 1998: 89-90).

Jevons holds that this main idea of maximising happiness by buying pleasure at the lowest possible cost is the goal of the economy and needs to be specified. Accordingly he focuses on "any object, substance, action or service which can afford pleasure or ward off pain" 13 . He argues that these are objects that can be classed as commodities because they have the quality of utility, in the sense of "the abstract quality whereby an object serves our purposes". Whatever can produce pleasure or prevent pain may possess utility, but mor- al considerations are avoided in the term. In short, Jevons asserts that "[a]nything which an individual is found to desire and to labour for must be assumed to possess for him utility. In the science of Economics, we treat men not as they ought to be, but as they are" (Jevons, 1998: 93-94).

This main idea thus translates as, or can be taken as equivalent to, meeting human needs at the lowest possible cost. In Jevons' opinion, we work to produce with the sole end of consumption, so "the theory of Economics must begin with a correct theory of consumption". He points out that many economists have held this to be clearly so and cites as an example Bastiat's ${ }^{14}$ assertion: "Wants, Efforts, Satisfaction -this is the circle of Political Economy" (Jevons, 1998: 95) ${ }^{16}$.

"Utility" and "happiness" are fully synonymous in Jevons' theory because, as he himself points out, "[u]tility must be considered as measured by, or even as actually identical with, the addition made to a person's happiness. It is a convenient name for the aggregate of the favourable balance of feeling produced", the sum of the pleasure created, and the pain prevented (Jevons, 1998: 98).

From there on, Jevons highlights the need to distinguish between the total utility arising from any commodity and the degree of utility (marginal utility) of the commodity at any point ${ }^{16}$. Utility (happiness) can be considered as a quantity with two dimensions: one comprises the quantity of the commodity (Jevons gives the example of the quantity of food) and is measured on the $\mathrm{x}$-axis; the other is the intensity of utility, and is measured on the y-axis, thus:

\footnotetext{
Jevons cites food, clothing, buildings, utensils, furniture, ornaments, etc. as examples.

14 Frédéric Bastiat (1801-1850), a French economist and intensely liberal thinker in the sense that he was a firm defender of laissez-faire and did not favour state intervention. He is generally considered as lightweight in his economic approach (Naredo, 1987: 130). One of his main ideas, which emerged from his optimistic, laissez-faire approach, was that free market formed of itself a harmonious mechanism that tended to favour the interests of individuals belonging to all social classes. According to Schumpeter, Bastiat's name "might have gone down to posterity as the most brilliant economic journalist who ever lived" had he not written his Harmonies économiques in 1850, a work that clearly exposed his scant powers of reasoning and his inability to handle the analytical apparatus of economics. However Schumpeter does admit out that his book cannot be said to be devoid of good ideas (Schumpeter, 1982: 561).

15 Jevons refers in this passage to Harmonies of Political Economy, the 1860 English translation by P.J. Stirling of Bastiat's Harmonies économiques. A Spanish version was published in 1855 under the title Armonías Económicas (Jevons, 1998: 95).

16 Total utility and Degree of Utility in the original. At that time these concepts were referred to by different names. In this regard Schumpeter points out that "As everybody knows, Léon Walras retained the term rareté; Gossen had spoken of utility of the last atom; Jevons introduced final utility and final degree of utility; the phrase marginal utility (Grenznutzen) is von Wieser's; Wicksteed suggested fractional utility, J. B. Clark specific utility, Pareto ophélimité élémentaire (Schumpeter, 1982: 1146).
} 


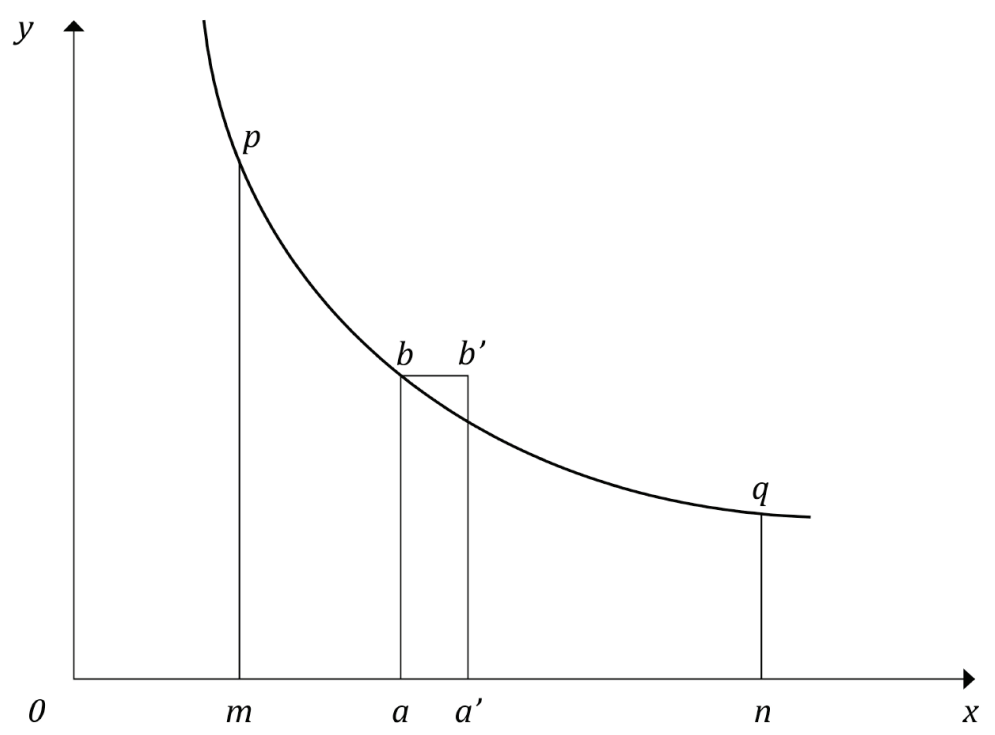

Figure 2: Total \& marginal utility from consumption of a good x. (Jevons, 1998: 100)

In Figure 2 oa represents $x$ and $a b$ is the degree of utility at the point $a$. Now, if we increase $x$ by the small quantity $a a$ 'or $\Delta x$, the utility is increased by the small rectangle $a b b^{\prime} a$ 'or $\Delta u$; and since a rectangle is the product of its sides, we find that the length of the line $a b$, the degree of utility, is represented by the fraction $\frac{\Delta u}{\Delta x}[\ldots]$ This way the limit of this fraction $\frac{\Delta u}{\Delta x}$ or, as it is commonly expressed, $\frac{d u}{d x}$, is the degree of utility corresponding to the quantity of commodity $x$ " (Jevons, 1998: 98-102).

The high level of detail with which we look here at what Jevons means by "utility" (total or marginal) is, we believe, justified because, in his theory, "utility" and "happiness" mean the same thing. Thus, the better we understand what Jevons means by utility, the more we will understand what he means by happiness within the field of economic theory. When he speaks of utility (happiness) he refers to the enjoyment or pleasure that a person derives from the consumption of goods purchased on the market. It could be concluded that this is a much simplified idea of happiness.

In short, Jevons sees the object of economics as being to maximise happiness by purchasing pleasure at the lowest possible cost. In that context, he clarifies that commodities are goods that have the abstract quality of utility, understood as the ability to produce pleasure or prevent pain. Commodities thus have utility to the extent that they provide pleasure or, equivalently for Jevons, provide happiness. Thus, he sees utility and happiness/pleasure as equivalent concepts which are fully identified and enter into economics to take up a position at the heart of neoclassical economics as the new object of study. The criterion for accepting or rejecting a given action depends on its effect on happiness, as maintained by the moral theory of utility. In other words, Jevons can be seen as asserting that economics is the science of happiness.

\subsection{Francis Ysidro Edgeworth (1845-1926)}

To set Edgeworth in the context of the topic under discussion here, we follow Joseph Schumpeter and begin by pointing to "his utilitarianism, which strongly asserted itself from the beginning", in his work New and Old Methods of Ethics (1877); a utilitarianism that "did much to keep alive -quite unnecessarily- the unholy alliance between economics and Benthamite philosophy" (Schumpeter, 1982: 909).

In 1881 Edgeworth, who is thought by authors such as Sen (Sen, 2010: 215) to be perhaps the best economic theorist of the late $19^{\text {th }}$ century, published his classic work on economic theory Mathematical Psychics: An Es- 
say on the Application of Mathematics to the Moral Sciences ${ }^{17}$.

In the mentioned work, Edgeworth supports the advisability of applying to the field of economics the same mathematical terms that are applied to physics, because "the conception of man as a pleasure machine may justify and facilitate the employment of mechanical terms and mathematical reasoning in social science" (Edgeworth, 2000: 56).

One of the problems faced in the field of pleasure is, says Edgeworth, that of measurement. He acknowledges, in contrast to what happens in physics, that we are far from finding a practical solution that would enable us to measure the pleasurable and painful feelings inherent in mental activity. Indeed, it is doubtful whether we can even conceive how such feelings or psychical phenomena might be measured. But given that mathematical reasoning requires the consideration of a unit of measurement, it must be assumed that there is a "unit of pleasure", understood as a "just perceivable increment" in pleasure, so as to be able to make quantitative calculations "which a man can form (I) of his own pleasure, and (II) of other people's." (Edgeworth, 2000: 133, Appendix III: On Hedonimetry).

Edgeworth suggests that we imagine a "psychophysical machine", which he calls a "hedonimeter", which continually registers the levels of pleasure experienced by an individual. Then "the quantity of happiness between two time periods is represented by the area contained between the zero-line, perpendiculars thereto at the points corresponding to the epochs, and the curve traced by the index". The axiom to be taken into account now is the following: "Any just perceivable pleasure-increment experienced by any sentient at any time has the same value". The aforesaid ideal mechanism is used here, again taking into account "the number of sentients and to integrate through all time and over all sentience, to constitute the end of pure utilitarianism" (Edgeworth, 2000: 135-136, Appendix III: On Hedonimetry).

This operation consists of updating or bringing together over time the pleasure that exists at each instant of time. In Edgeworth's opinion, it is "the end of rational action, whether self-interested or benevolent" (Edgeworth, 2000: 53).
Edgeworth holds that there are two approaches to the calculation of pleasure: the "economical calculus", which "investigates the equilibrium of a system of hedonic forces each tending to maximum individual utility" and the "utilitarian calculus", which investigates "the equilibrium of a system in which each and all tend to maximum universal utility" (Edgeworth, 2000: 59).

In reference to the "economical calculus" or calculus of maximum individual utility, he holds that " $(\mathrm{t})$ he first principle of Economics is that every agent is actuated only by self-interest". From this perspective, Edgeworth considers that it may happen that economic agents act without or with the consent of others affected by his actions. He describes the first case as a case of "war" and the second as one of "contract" (Edgeworth, 2000: 60).

Edgeworth then looks in detail at the possibility that contracts may be conducted in contexts of perfect competition, and at the contractual uncertainties and problems that arise from cases in which markets suffer from one or more imperfections. In such cases, he says in regard to indeterminate contracts that deadlock is reached, i.e. a situation of opposition of interests in which the "pleasure-forces of the contractors are mutually antagonistic" (Edgeworth, 2000, 70-71).

He argues that the impossibility of carrying out contracts, i.e. deadlock, would "impair [...] the reverence paid to competition", in whose results economists have complacently acquiesced, as if they came directly from Nature or from a play of physical forces and were impersonal and impartial. In such cases, Edgeworth says, if respect for competition were lost then a need would arise for a "principle of arbitration" that could redirect contracts and put an end to conflicts. "This aspiration of the commercial world would be but one breath in the universal sigh for articles of peace" (Edgeworth, 2000: 88).

Edgeworth then goes on to ask this: if competition needs to be supplemented by arbitration, what should the guiding principle of that arbitration be? In this regard, Edgeworth maintains that although equity and justice are moral principles to be considered, they would not be directly applicable to the problem of the distribution of a joint product between co-op- 
erators -"the star of justice affords no certain guidance". Justice, he says, requires to be informed by some more definite principle; he points specifically to the principle of utilitarianism. In short, "competition requires to be supplemented by arbitration, and the basis of arbitration between self-interested contractors is the greatest possible sum-total utility. Thus the economical leads up to the utilitarian calculus" (Edgeworth, 2000: 89 - 92).

After reaching this conclusion he presents details of the utilitarian calculus by setting the following problem (Edgeworth, 2000: 93):

To find $(\alpha)$ the distribution of means and $(\beta)$ of labour, the $(\gamma)$ quality and $(\delta)$ number of population, so that there may be the greatest possible happiness.

Definitions:

1. Pleasure is used for "preferable feeling" in general [...]. The term includes absence of pain. Greatest possible happiness is the greatest possible integral of the differential "number of enjoyers $\times$ duration of enjoyment $\times$ degree thereof".

2. Means are the distributable proximate means of pleasure, chiefly wealth as destined for consumption and $[. .$.$] the unpur-$ chased command of unproductive labour.

3. An individual has greater capacity for happiness than another when for the same amount of whatsoever means he obtains a greater amount of pleasure, and also for the same increment (to the same amount) whatsoever of means a greater increment of pleasure.

4. An individual has more capacity for work than another when for the same amount whatsoever of work done he incurs a less amount of fatigue, and also for the same increment (to the same amount) whatsoever of work done a lesser increment of fatigue.

In the context of the problem Edgeworth assumes that "pleasures may therefore be measured, and [...] all pleasures are commensurable" and that, under Bain's Law of
Accommodation", "the rate of increase of pleasure decreases as its means increase". Finally, regarding the initial conditions of the problem, he starts from the assumption that "each individual has and shall retain that minimum of means just sufficient to bring him up to the zero-point of happiness (a conception facilitated by, though not quite identical with, the economical "natural minimum of wages')" (Edgeworth, 2000: 93-98).

With the problem set out in these terms, Edgeworth asks how successive increments in means $(\alpha)$ should be distributed among different individuals. He discusses certain details and examines several specific cases, but the core of his explanations lies in this idea: given that the capacity for happiness differs from one individual to another, the means should assigned as "felicifically" as possible (Edgeworth, 2000: 99), i.e. in such a way that the highest overall level of happiness is attained. This, he states, will be achieved when the increments in means are distributed in direct relation to the capacities for happiness. He asserts that "the distribution of means as between the equally capable of pleasure is equality; and generally is such that the more capable of pleasure shall have more means and more pleasure" (Edgeworth, 2000: 99).

The distribution of work $(\beta)$ must, Edgeworth says, take place according to an equivalent criterion. Once individuals are arranged according to their capacity for work "the distribution of labour between the equally capable of work is equality, and generally is such that the most capable of work shall do more work -so much more work as to suffer more fatigue" (Edgeworth, 2000: 101).

Taking into account the distribution of means $(\alpha)$ and work $(\beta)$ stated above, the greatest possible happiness is given by the greatest possible value of $V$ in the expression:

$$
V=\int_{x_{0}}^{x_{1}} n[F(x y)-p-c\{y-f(x p)\}] d x
$$

where: $x$ is the degree of any capacity; $x_{0}$ and $x_{1}$ are the given limits of integration; $n$ is the number of each section; $F(x y)$ is a unit's

\footnotetext{
18 The Spencer-Bain principle: observations made initially by Bain and subsequently by Spencer concerning the fact that behaviour which results in pleasurable consequences tends to be repeated, while that which has painful consequences tends not to be. http://innova.decp.uam.es/publi/descarga.php?UID=\&id=2147505715\&profesor=72.

Edgeworth maintains that an increase in means does not produce a proportional increase in pleasure, and indeed that the same means produce less pleasure. In that context he cites Bain's Law of Accommodation and asserts that in accordance with it an increase in means permits a proportional increase in the repetition of the conditions of pleasure and therefore does not permit a proportional increase in pleasure (Edgeworth, 2000: 98).
} 
pleasure of consumption (with $x$ being capacity for pleasure and $y$ its means); $p$ is a unit's pain f work; $c$ is the constant incidental to problems of relative maximum; $f(x p)$ is the work done by the unit, being a function of the quality (capacity for work) and fatigue (effort).

The greatest value of $V$ may require an unequal distribution of means and of work because, contends Edgeworth, "equality is not the whole of distributive justice": there may be a need for "deserved unequal distribution". He argues firmly in favour of the aristocratic privilege of man above brute, of civilised above savage, and of the man over woman ${ }^{19}$ : a privilege "of birth, of talent, and of the male sex". According to the cited utilitarian principle, the basis for those privileges lies in "supposed differences of capacity" for pleasure and pain between aristocrats and the lower classes. Thus "capacity for pleasure is a property of evolution, an essential attribute of civilisation". He also considers that "production is an unsymmetrical function of manual and scientific labour" and that Economics may afford deeper reasons that justify differences in the remuneration and the allocation of more agreeable work to the aristocracy of skill and talent ${ }^{20}$ (Edgeworth, 2000: 102-111).

Edgeworth continues with the utilitarian calculus, focusing on quality $(\gamma)$ [he refers to the quality of the population]. He argues that individuals should strive to attain the highest possible degree of evolution [meaning capacity for pleasure]. Indeed, when he refers to "quality" this should be understood as a greater capacity for pleasure, which he sees as equivalent to "high quality" of population. In this regard he asserts that although it may seem desirable to advance the whole population by the same degree of evolution, this might not be the most desirable application given the "quantity of means of education". It is probable that the highest in the order of evolution are the most capable of education and improvement. Thus, Edgeworth recommends that "in the general advance the most advanced should advance most" (Edgeworth, 2000: 103).

The last unknown in the utilitarian calculus problem is $(\delta)$ the size of the population. Edgeworth reflects on the current population and the desirable rate of population growth taking the Malthusian theory of population into account, albeit with reservations. He seeks not to provide definitive solutions but to "indicate an ideal" though it can only be approached with moderation, in accordance with human nature. Accordingly, he suggests that it might be desirable to agree upon some system of selection of descendants that is beneficial so that the happiness of each succeeding generation is always as great as possible. The average number of descendants of the classes selected, over and above a given degree of capacity for pleasure, should be high and that of the lower classes practically zero. Edgeworth states that "(a)gain, mitigations might be provided for the classes not selected". At this point he cites Galton $^{21}$ and Sully ${ }^{22}$ and writes in a footnote that " $(t)$ he weak could find a welcome and a refuge in celibate monasteries" (Edgeworth, 2000: 105).

In the last two pages (excluding the appendices) of Mathematical Psychics Edgeworth insists that "(p)ending a scientific hedonimetry, the principle "[e]very man, and every

19 In regard to the superiority of men over women, Edgeworth argues that men have a supposedly superior capacity for happiness, for the energies of action and contemplation; and upon the sentiment "woman is the lesser man, and her passions unto mine are as moonlight unto sunlight and as water unto wine". He argues that her supposed generally inferior capacity is supposed to be compensated by a special capacity for emotions, certain kinds of beauty and refinement. Thus, under Utilitarian theory it is natural that they should have received a larger share of certain means, certain luxuries and attentions; and also some exemptions from harder work. In short, Edgeworth argues that "account being taken of existing, whether true or false, opinions about the nature of woman, there appears a nice consilience between the deductions from the utilitarian principle and the [...] privileges which hedge around modern womanhood".

20 Edgeworth argues that, in line with the utilitarian principle of the greatest overall happiness, the happiness of some of the lower classes may be sacrificed to that of the higher classes, and that the happiness of part of the second generation may be sacrificed to that of the succeeding generations. He admits, however, that there should be a required limit of happiness, which cannot be less than zero and must be above the starving point. Negative happiness and starvation could lead to discomfort in the lower classes and falls in population levels. Politics and the political economy must set some such limit above zero (Edgeworth, 2000: 108)

21 Francis Galton (1822-1911) was a geographer, meteorologist, explorer and statistician. He is considered as the founder of differential psychology. He was a half-cousin of Charles Darwin. He applied his principles to numerous fields, mainly the study of human beings and individual differences. http://galton.org/

22 James Sully (1842-1923) was an English philosopher and psychologist whose views had great affinity with those of Alexander Bain. http://en.wikipedia.org/wiki/James_Sully. The work by Sully to which Edgeworth refers is Pessimism, published in 1877. 
woman, to count for one" should be very cautiously applied". Nor is he a supporter of universal suffrage. He favours a system of "plural votes" conferred according to the sagacity of individuals and their capacity for happiness. Finally, he argues for conservative caution in reforms that can, following the guidelines of the utilitarian principle, bring humanity closer to the best of all possible worlds (Edgeworth, 2000: 112-114).

\section{Conclusions}

Both Jevons and Edgeworth attempted to refound the science of economics taking as their basis hedonistic individuals who seek to maximise their own pleasure, happiness or utility. This means that, in the words of Luigino Bruni, "it is not true that happiness is not central in neoclassical economics" (Bruni, 2006: 106); however we must not lose sight of the fact that the type of happiness that one seeks to maximise in the context of acquiring pleasure at the lowest possible cost is a simplified form of happiness.

It must be pointed out that this simplified happiness was soon to be expelled from the field of economic theory by the work of economists such as Pareto, Robbins and, to a lesser extent, Wicksteed. The cardinal concept of utility adopted by the early Utilitarians was to be replaced by an ordinal approach linked, as is well known, to the so-called logic of rational choice.

It is not clear where these new theoretical and, above all, empirical works on measuring happiness and utility are taking us, but we are convinced that economics will be improved by this new shift. One possible extension of our analysis here would be to investigate whether there would have been a more fruitful relationship between economics and politics if the Jevons-Edgeworth methodological project had not been side-lined for much of the $20^{\text {th }}$ century.

\section{References}

Abramovitz, M. (1959). The Welfare Interpretation of Secular Trends in National Income and Product. In The Allocation of Economic Resources: Essays in honour of Bernard Francis Haley (pp. 1-22). California: Stanford University Press

Brickman, P \& Campbell, D.T. (1971). Hedonic relativism and planning the good society. In M. H. Apley (Eds.), Adaptation-level theory: A symposium (pp. 287-302). New York: Academic Press.

Bruni, L. (2006). Civil Happiness, Economics and human flourishing in historical perspective. US and Canada: Routledge.

Bruni, L. (2007). The "technology of happiness" and the tradition of economic science. In Bruni y Porta (Eds), Handbook on the Economics of Happiness (pp. 24-52). UK: Edward Elgar Publishing.

Cachón, E. (2013). Crisis, empleo y felicidad: El caso de los trabajadores ocupados en España en 2007 y 2010. Madrid: Universidad Autónoma de Madrid, Doctoral Thesis.

Clark, A.E. (2016). SWB as a Measure of Individual Well-Being. In M.D. Adler, M. Fleurbaey (Eds): The Oxford Handbook of Well-Being and Public Policy (pp. 518-552), Oxford University Press, New York.

Colander, D. (2007). Edgeworth's Hedonometer and the Quest to Measure Utility. Journal of Economic Perspectives, 21 (2), 215-225.

http://sandcat.middlebury.edu/econ/repec/mdl/ancoec/0723.pdf

Duesenberry, J.S. (1972). La renta, el ahorro y la teoría del comportamiento de los consumidores. Alianza, Madrid.

Easterlin, R.A. (1974). Does economic growth improve the human lot? Some empirical evidence. In P.A. Davis, M.W. Reder, (Eds.): Nations and households in economic growth (pp. 89-125) New York, Academic Press.

Edwards, J.M. (2009). Joyful economists: remarks on the history of economics and psychology from the happiness studies perspective. Economies and finances. Université Panthéon-Sorbonne, Paris I. https:// halshs.archives-ouvertes.fr/tel-00486771/document

Edgeworth, F.I. (2000). Psicología Matemática [1881]. Madrid, Pirámide.

Esteve, F. (2008). Hedonismo y Eudemonismo. Un camino de ida y vuelta por la nueva economía de la felicidad. http://portal.uam.es/portal/page/profesor/epd2_profesores/prof108/publicaciones

Esteve, F. \& Muñoz de Bustillo, R. (2005). Conceptos de Economía. Alianza, Madrid. 
Ferrer-i-Carbonell, A. (2011). Economía de la felicidad. Els Opuscles del CREI 28.

Ferrer-i-Carbonell, A. (2013). Happiness economics. SERIEs, 4, 35-60.

Frank, R.H. (1997). The Frame of Reference as a Public Good. The Economic Journal, (107), 1832-1847.

Frey, B.S. (2008). Happiness. A Revolution in Economics. Cambridge: The MIT Press

Galbraith, J. (2008). La sociedad opulenta [1958], Ariel, Barcelona.

Hacker, J.S. \& Pierson, P. (2010). Winner-take-all politics: Public policy, political organization, and the precipitous rise of top incomes in the United States. Politics and Society, (38), 2, 152-204. http://pas. sagepub.com/content/38/2/152.full.pdf + html

Hirsch, F. (1976). Social Limits to Growth. Cambridge, Mass.: Harvard University Press.

Iglesias, E., Pena, J. A. \& Sánchez, J. M. (2013). Bienestar subjetivo, renta y bienes relacionales. Los determinantes de la felicidad en España. Revista Internacional de Sociología, (71), 3, 567-592.

Jevons, W.S. (1998). La Teoría de la Economía Política [1871]. Madrid: Pirámide.

Kahneman, D. \& Sugden, R. (2005). Experienced utility as a standard of policy evaluation. Environmental and Resource Economics (32), 1, 161-181.

Kant, I. (2007). Fundamentación de la Metafísica de las Costumbres [1785]. Edition by Pedro M. Rosario Barbosa. San Juan, Puerto Rico. http://pmrb.net/books/kantfund/fund_metaf_costumbres_vD.pdf

Layard, R. (2005). La felicidad. Lecciones de una nueva ciencia. Madrid: Taurus.

Malthus, T.R. (1798). An Essay on the Principle of Population. Oxford: Oxford University Press.

Malthus, T.R. (2008). Los Principios de Economía Política [1820]. Madrid: Instituto de Estudios Fiscales.

Naredo, J.M. (1987). La Economía en evolución. Madrid: Siglo XXI.

Ng, Y. K. (1997). A Case for Happiness, Cardinalism, and Interpersonal Comparability. The Economic Journal, (107), 1848-1858. http://www.colorado.edu/economics/morey/4999Ethics/Ng1997.pdf

Oishi, S., Kesebir, S. \& Diener, E. (2011). Income Inequality and Happiness. Psychological Science, (22), 9, 1095-1100. http://www.factorhappiness.at/downloads/quellen/S13_Oishi.pdf

Oswald, A.J. (1997). Happiness and Economic Performance. The Economic Journal, (107), 1815-1831.

Pasinetti, L. (2005). Paradoxes of Happiness in Economics. In Bruni y Porta (Eds), Economics \& Happiness (pp. 336-343). New York: Oxford University Press.

Peiró, A. (2004). Condiciones socioeconómicas y felicidad de los españoles. Boletín Económico del ICE (816) 179-194.

Robinson, J. (1953). On Re-Reading Marx. Students’ Bookshops LTD., Cambridge. http://collections.mun. ca/PDFs/radical/OnReReadingMarx.pdf

Rojas, M. (2009). Economía de la felicidad. Hallazgos relevantes respecto al ingreso y el bienestar. El Trimestre Económico (76), 3, 537-573.

Russell, B. (2006). The Conquest of Happiness [1930], Routledge, London.

Schumpeter, J.A. (1982). Historia del Análisis Económico [1954], Ariel, Barcelona.

Scitovsky, T. (1976). The Joyless Economy. Oxford University Press, New York. Spanish version: Frustraciones de la riqueza (1986) FCE, México.

Sen, A.K. (2010). La idea de la Justicia [2009], Taurus, Madrid.

Smith, A. (1759). La Teoría de los Sentimientos Morales, Alianza Editorial, Madrid, 1997.

Smith, A. (1776). Investigación sobre la Naturaleza y Causas de la Riqueza de las Naciones, Oikos-Tau, Barcelona, 1988.

Stevenson, B. \& Wolfers, J. (2008). Economic Growth and Subjective Well-Being: Reassessing the Easterlin Paradox. NBER Working Papers Series. Working Paper 14282. http://www.nber.org/papers/ w14282.pdf?new_window $=1$

Stiglitz, J; Sen, A; Fitoussi, J.P. (2009a). Report by the Commission on the Measurement of Economic Performance and Social Progress. www.stiglitz-sen-fitoussi.fr.

Stiglitz, J; Sen, A; Fitoussi, J.P. (2009b). Informe de la Comisión sobre la Medición del Desarrollo Económico y del Progreso Social. http://www.ambafrance-es.org/IMG/pdf/Commission_Stiglitz_ES.pdf

Veblen, T. (1989). The Theory of the Leisure Class [1899], Macmillan, New York. Spanish version: Teoría de la clase ociosa (2005). Fondo de Cultura Económica. 